
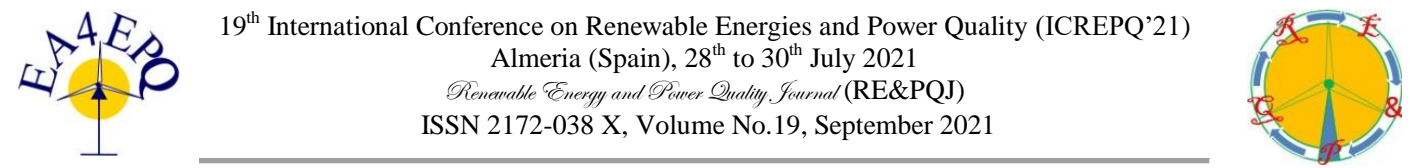

\title{
Determination PV Module Technical Condition
}

\author{
M. Belik ${ }^{1}$, O. Rubanenko \\ ${ }^{\mathbf{1}}$ Department of Electrical Power Engineering and Ecology \\ University of West Bohemia \\ Univerzitni 8, 30614 Plzen (Czech republic) \\ Phone/Fax number:+00420 377 634315, e-mail: belik4@kee.zcu.cz \\ ${ }^{2}$ Department of Electric Stations and Systems \\ Vinnytsia National Technical University \\ Khmelnytsky highway 95, 21021 Vinnytsya (Ukraine) \\ Phone/Fax number:+380977480285, e-mail: olenarubanenko@ukr.net
}

\begin{abstract}
The paper focuses on the determination of technical conditions and degradation of photovoltaic modules installed in grid-on operated photovoltaic systems in Ukraine and the Czech Republic. Detected malfunctions of PV modules are classified and Fault Tree Analyses (FTA) is created for particular PV modules. For assessment of the technical condition of the PV modules it is proposed to use residual resource index (RRI), that is being successfully used for determination of technical condition of transformers, breakers and synchronous generators. The main contribution is the method for the detection of photovoltaic modules condition with the use of a neuro-fuzzy network based on the experience of operational (maintenance) staff of particular plants.
\end{abstract}

Key words. Photovoltaic panels, technical condition, residual resource coefficient.

\section{Introduction}

Renewable energy sources become an integral part of electric power systems. Long-term prediction of the RES power generation is promised strong growth as demonstrated on Fig.1[1, 2].

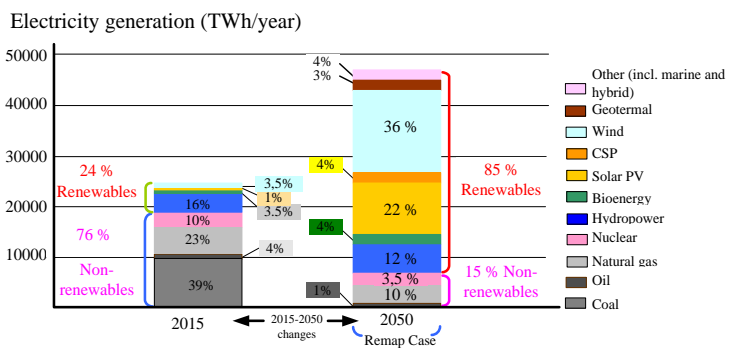

Fig. 1. Global prediction of renewable sources power generation.

Obviously, they should be optimally integrated into electrical networks, increasing the power generation and improving the technical and economic performance of electrical networks. As of February 2021, the installed

The paper was supported by SGS-2021-018 capacity of RES equipment in Ukraine is $6734 \mathrm{MW}$, including solar power plants (SES) - 80.54\%, which are non-guaranteed power plants (power plants that use unstable natural energy resources) in Ukraine [3, 4].

The situation in the Czech Republic shows similar progress - more than $20000 \mathrm{MW}$ installed in the photovoltaic. Nevertheless, despite the multiple benefits of using RES taking into account the growth in installed power, there are several new challenges that are observed.

When studying the instability of non-guaranteed energy sources, in addition to weather conditions, which are stochastic in nature, it is also important to determine their technical condition. Therefore, studies have been conducted on several examples of PV power plants. Since the PV modules are the main element of PV power plants, consider the definition of their technical condition in more detail [3].

The goal of this paper is to determine PV modules condition and plant statement with the use of neuro-fuzzy network based on the experience of operational (maintance) staff.

\section{Malfunctions of photovoltaic modules}

Fig. 2 - 5 present malfunctions detected in winter 2021 on the photovoltaic array in ground-based PV plant "Pisarivska", installed in the eastern part of Ukraine. This PV plant realizes generated electricity at the "green tariff" (15.99 Eurocents per $1 \mathrm{kWh}$ ).

The PV plant "Pisarivska" was commissioned into operation in 2016, and the efficiency of the production decreased to $12 \%$ in 5 years. Operational personnel explained that more often malfunctions happened with cable transmission lines (moisture in the insulation, 
consequently resulting fastly decreasing resistance) as shown on Fig. 3.

Also, operational personnel noted that some malfunctions of PV modules are difficult to predict (broken glass, supporting construction failures, etc...). The operational staff only have information obtained from the invertor. If some problem occurs, it is necessary to check all PV modules in particular string.

Table I presents in detail various malfunctions classified by the type of malfunction of the PV modules detected in Pisarivska $[6,7]$.

Fig. 2 shows typical examples of the hotspot - the most serious malfunction from detected. In the plant in Pisarivska there were 117 hotspots detected what means more than $25 \%$ of all problems.
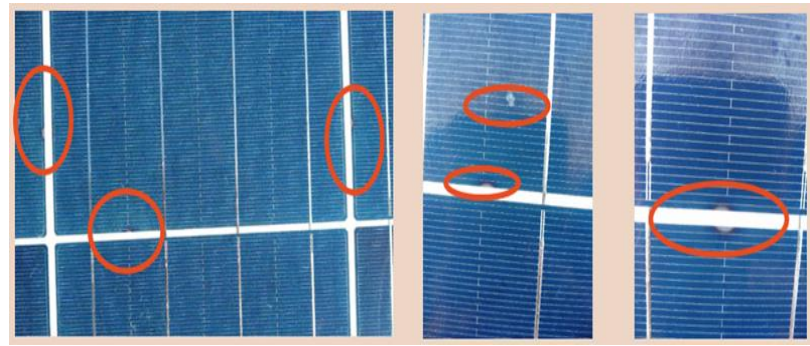

Fig. 2. Hotspots (Pisarivska, UKR, 2021).

The most common was the less serious problem. Various signs of the local pollution (Fig. 3) were identified in almost $40 \%$ cases. Although these cases are not serious they can lead to a massive biological or chemical corrosion with significant impact on panels.

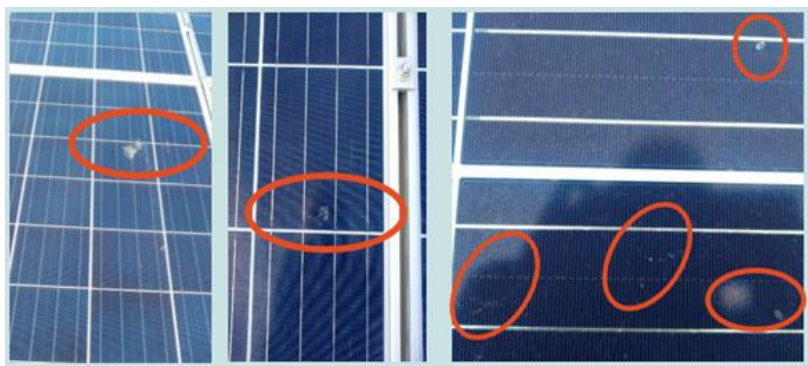

Fig. 3. Local pollution (Pisarivska, UKR, 2021).

Typical behaviour of cell degradation affecting the EVA cover are demonstrated on Fig. 4. The most common feature of this problem is darkened or browned colour of particular area. This situation is also often conclusions from hotspots. Fig. 5 shows samples of mechanical defects (broken glass and sealing degradation).
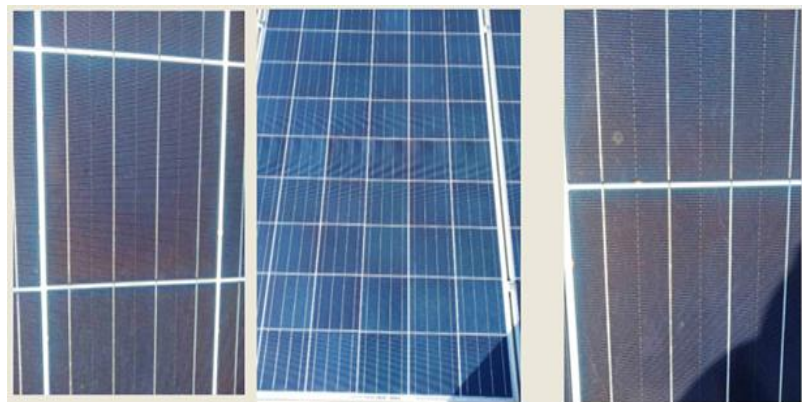

Fig. 4. Cell degradation (Pisarivska, UKR, 2021).
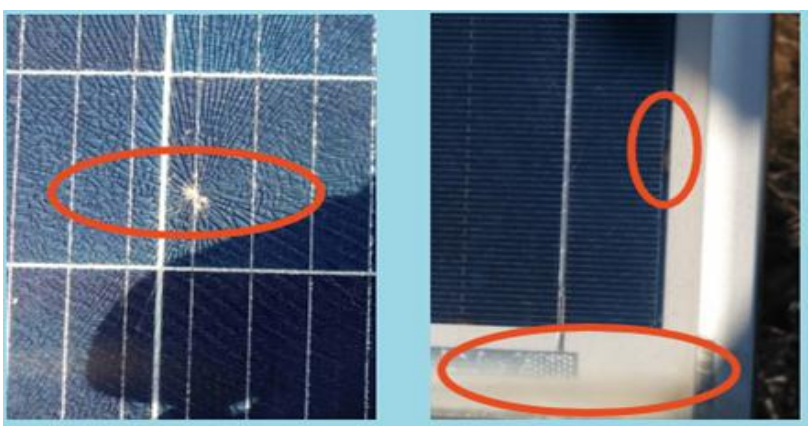

Fig. 5. Mechanical defects (Pisarivska, UKR, 2021).

Table I.- Malfunction classification (Pisarivska,UKR)

\begin{tabular}{|c|c|c|c|c|c|}
\hline $\begin{array}{c}\text { PVM } \\
\text { element }\end{array}$ & Type of Malfunction & Result & Parameter & & $\begin{array}{l}\text { Damage, } \\
\text { units; } \\
\text { Actiog \% }\end{array}$ \\
\hline \multirow[t]{2}{*}{ cell } & $\begin{array}{l}\text { breakdown of the } \\
\text { semiconductor junction }\end{array}$ & $\begin{array}{l}\text { above the normalized decrease in the } \\
\text { resitance of the photodiode in the opposite } \\
\text { direction - a decrease in the resistance of the } \\
\text { cell }\end{array}$ & $\begin{array}{l}\text { Photodiode } \\
\text { resistance, Ohm }\end{array}$ & \multirow[t]{2}{*}{$\begin{array}{l}k_{1}, \\
\text { ru. }\end{array}$} & \multirow{2}{*}{$\begin{array}{l}101 \text { units } \\
0.034 \text { r.1.: } \\
3.36 \%\end{array}$} \\
\hline & cell burnout & $\begin{array}{l}\text { break of comnecting conductors (flat busbar } \\
\text { bus) that connect the cell to the PVM }\end{array}$ & $\begin{array}{l}\text { Resistance } \\
\text { wires, Ohm }\end{array}$ & & \\
\hline \multirow{2}{*}{ busbar } & $\begin{array}{l}\text { deterionation of contact at } \\
\text { the junction of the cell } \\
\text { and the bus }\end{array}$ & $\begin{array}{l}\text { increase in temperature at the point of contact } \\
\text { and decrease in current }\end{array}$ & $\begin{array}{l}\text { Temperature, }{ }^{\circ} \mathrm{C} \\
\text { Current, } \mathrm{A}\end{array}$ & \multirow{2}{*}{$\begin{array}{l}k_{2}, \\
\text { r.u. }\end{array}$} & \multirow{2}{*}{$\begin{array}{l}43 \text { units, } \\
0.014 \mathrm{ran} ; \\
1.43 \%\end{array}$} \\
\hline & $\begin{array}{l}\text { corrosion } \\
\text { Schottly diode damage } \\
\text { (brealkdown) }\end{array}$ & $\begin{array}{l}\text { current reduction, busbar heating } \\
\text { heating }\end{array}$ & \begin{tabular}{|l|} 
Current, A \\
Temperature, ${ }^{\circ} \mathrm{C}$ \\
Current, A
\end{tabular} & & \\
\hline unctionbox & $\begin{array}{l}\text { due to the resistance of } \\
\text { the contacts }\end{array}$ & heating & $\begin{array}{l}\text { Temperature, }{ }^{\circ} \mathrm{C} \\
\text { Current, } \mathrm{A}\end{array}$ & $\begin{array}{ll}k_{3} \\
\text { r.u. }\end{array}$ & $\begin{array}{l}2504 \text { units; } \\
0.833 \text { in: } \\
83.3 \%\end{array}$ \\
\hline $\begin{array}{l}\text { aluminum } \\
\text { frame with } \\
\text { sealant }\end{array}$ & $\begin{array}{l}\text { deterioration of the } \\
\text { tightness of the frame }\end{array}$ & heating, moisture inside the PVM & $\begin{array}{l}\text { Temperature, }{ }^{\circ} \mathrm{C} \\
\text { Cunrent, } \mathrm{A}\end{array}$ & $\begin{array}{l}k_{4,} \\
\text { r.u }\end{array}$ & $\begin{array}{c}54 \text { units, } \\
0.018 \mathrm{nu} ; \\
1.8 \%\end{array}$ \\
\hline $\begin{array}{l}\text { protective } \\
\text { glass }\end{array}$ & corrosion & heating, moisture inside the PVM & $\begin{array}{l}\text { Temperature, }{ }^{\circ} \mathrm{C} \\
\text { Current, } \mathrm{A}\end{array}$ & $\begin{array}{l}\text { ks, } \\
\text { r.u }\end{array}$ & $\begin{array}{l}80 \text { muts, } \\
0.027 \text { r.⿲丿; } \\
2.66 \%\end{array}$ \\
\hline $\begin{array}{l}\text { cable } \\
\text { comnecting } \\
\text { cells to the } \\
\text { terminal }\end{array}$ & cable damage & insulation and resistance of the comnector & $\begin{array}{l}\text { Resistance of } \\
\text { wires, Ohm } \\
\text { Temperature }^{\circ} \mathrm{C}\end{array}$ & $\begin{array}{l}k_{6, x} \\
r . u\end{array}$ & $\begin{array}{l}225 \text { units, } \\
0.075 \mathrm{ru} \\
7.48 \%\end{array}$ \\
\hline
\end{tabular}

Following figures present examples of similar malfunctions detected between 2004 and 2021 on the photovoltaic plant installed on the university building in Pilsen (Czech Republic). This plant is one of the first commercial PV plants in Czech Republic and can serve as a contrapole of the relatively new Pisarivska plant. Fig. 6 shows very common delamination. This issue started to appear during 2018 after 14 years of operation.

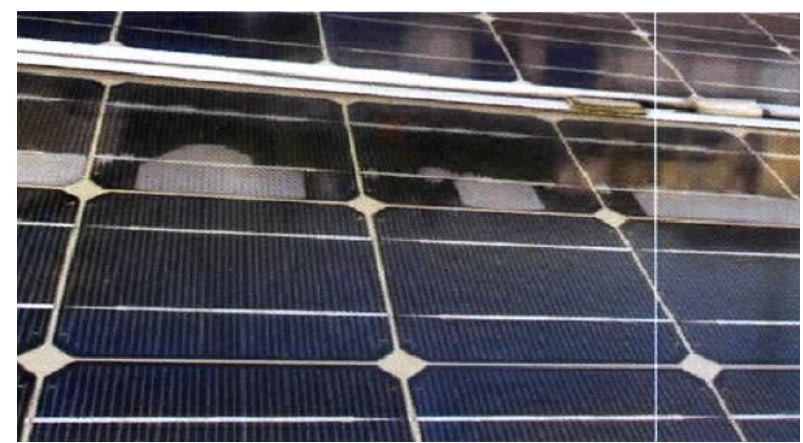

Fig. 6. Example of a delamination (Pilsen, CR, 2018 - 2021).

Another serious issue detected on Pilsen plant is demonstrated on Fig. 7. It is evident that back sides of the panels suffer with huge biological corrosion. Similar problems, but in a larger scale, were found also in Busanovice plant (CR) built on wooden structures.

These problems lead in praxis into serious commercial looses and also opens interesting technical problems. This malfunctions can affect (not just) positioning of affected panels leading to panel mismatch and further thermal overload resulting in shorter life of the panel. Also ohmic looses or shunt current can occure with the same results. 


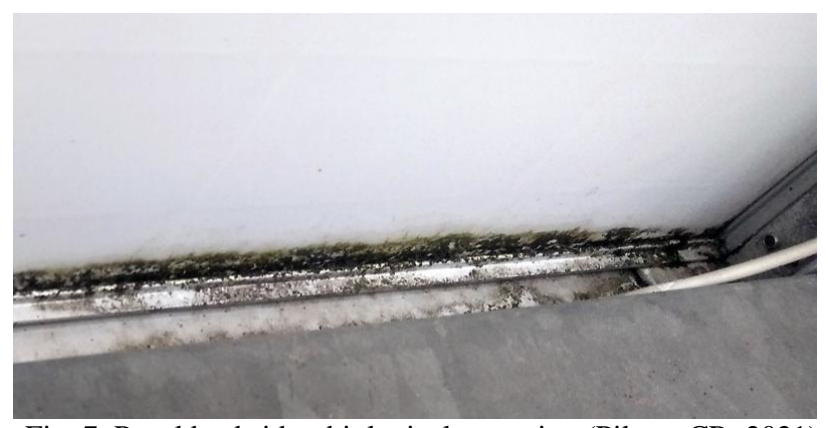

Fig. 7. Panel backside - biological corrosion (Pilsen, CR, 2021).

Fig. 8 demonstrates that loose cables suffer either with UV radiation degradation or with biological corrosion in the same way as the panels itself. Example is from Pilsen plant as well. Table II summarizes particular malfunctions detected on this system. The exposition to ambient conditions means serious stress for used materials.

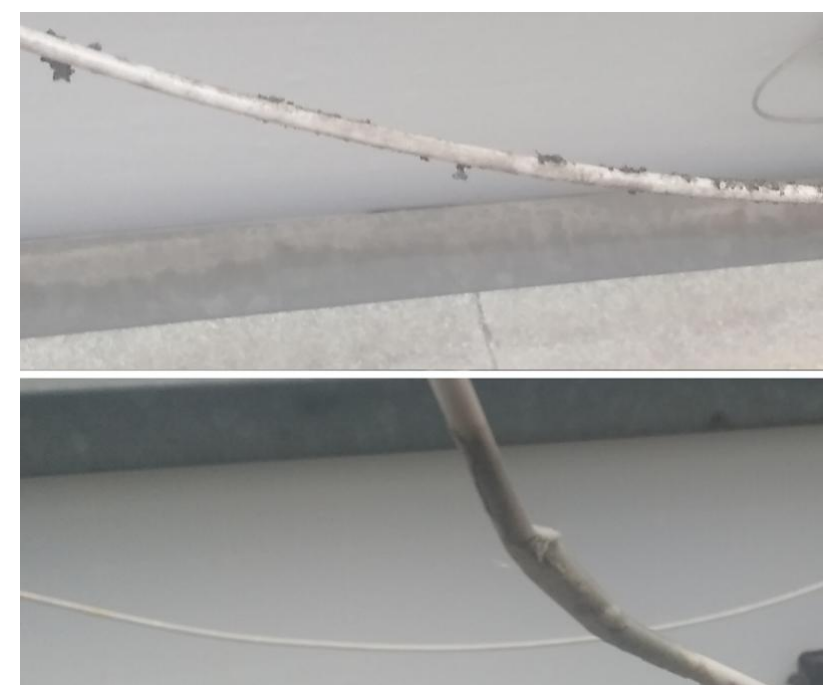

Fig. 8. Cable degradation and corrosion (Pilsen, CR, 2021).

Table II. - Various malfunction classified by the type of malfuction and the PV module element (Pilsen, CR)

\begin{tabular}{|c|c|c|c|}
\hline \multirow{2}{*}{ Malfunction } & \multicolumn{2}{|c|}{ Percentage } & \multirow{2}{*}{ Exposure } \\
\hline & - & $\%$ & \\
\hline aerial pollution & 128 & 39,7 & dust layer and traces \\
\hline cell degradation & 117 & 27,2 & colour changes \\
\hline cell hotpot & 37 & 8,5 & local overheating \\
\hline cell microcrack & 36 & 8,4 & crack \\
\hline metalisation defect & 34 & 8,1 & broken conductors \\
\hline bus defect & 19 & 4,4 & soldering corrosion \\
\hline snail traces & 18 & 4,1 & material degradation \\
\hline low transparency & 15 & 3,7 & glass / EVA degradation \\
\hline EVA yellowing & 9 & 2,1 & EVA degradation \\
\hline local pollution & 8 & 1,9 & birds excrements \\
\hline bad connector box & 5 & 1,2 & corrosion, PVC degrade. \\
\hline bad wire connection & 3 & 0,9 & overheating, corrosion \\
\hline moisture inside panel & 1 & 0,4 & delamination \\
\hline broken glass, EVA & 1 & 0,4 & mechanical impact \\
\hline Total & 431 & 100 & \\
\hline
\end{tabular}

As evident from the table, 431 particular malfunction affected installed panels. There are 192 panels and approximately $27 \%$ is affected with some kind of degradation or malfunction, what affects the power genaration for $11,6 \%$.
Continuous measurements on the plant are used as the input for aging simulations and analyses in 20 years period. Results of the simulation in PV Syst are presented in Table III and further could be used as a correction curve in the FTA.

Table III. - Aging simulation - PV Syst (Pilsen, CR)

\begin{tabular}{|c|c|c|c|}
\hline \multicolumn{4}{|c|}{ FEL Z U MN73 SYN } \\
\hline Year & E Grid & $P R$ & PRloss \\
\hline & MWn & & 5 \\
\hline 1 & 19.14 & 0.768 & $0 \% 8$ \\
\hline 2 & 19.05 & 0.764 & $-0.5 \%$ \\
\hline 4 & $\begin{array}{l}18.96 \\
18.86\end{array}$ & $\begin{array}{l}0.76 \\
0.757\end{array}$ & -1.48 \\
\hline 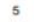 & 18.76 & 0.753 & -25 \\
\hline 6 & 18.66 & 0.748 & $.2 .5 \%$ \\
\hline 7 & 18.55 & 0.744 & -3.18 \\
\hline 8 & 18.44 & 0.739 & $-3.7 \%$ \\
\hline 9 & 1832 & 0.735 & $-4.3 \%$ \\
\hline $\begin{array}{l}10 \\
11\end{array}$ & $\begin{array}{l}18.20 \\
18.07\end{array}$ & $\begin{array}{l}0.73 \\
0.725\end{array}$ & $\begin{array}{l}-4.9 \% 6 \\
-5.6 \%\end{array}$ \\
\hline 12 & 17.94 & 0.72 & $-6.3 \%$ \\
\hline 13 & 17.81 & 0.714 & $.7 \mathrm{~K}$ \\
\hline 14 & 17.68 & 0.709 & $-7.6 \%$ \\
\hline 15 & 17.54 & 0.704 & $-8.3 \%$ \\
\hline 16 & 17.41 & 0.698 & $-90 \%$ \\
\hline 18 & 17.17 & 0.689 & $-10.3 \%$ \\
\hline 19 & 17.04 & 0.684 & $-11 \%$ \\
\hline & & & \\
\hline
\end{tabular}

Shape of the correction curve is presented on Fig. 9. Accuracy of this correction curve was compared to real measurements on Pilsen plant from 2009 to 2018.

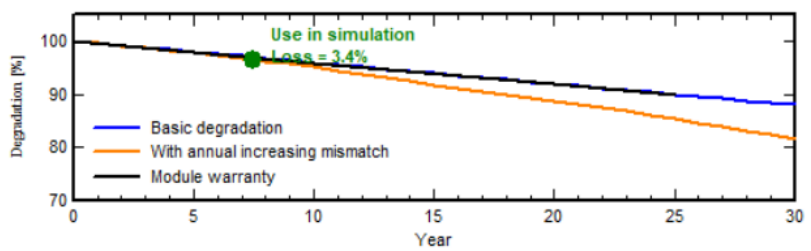

Fig. 9. Aging correction curve.

Table IV. - Simulation uncertainity (Pilsen, CR)

\begin{tabular}{|l|l|l|l|}
\hline & $\begin{array}{c}\text { Generation } \\
{[\mathrm{kWh}]}\end{array}$ & $\begin{array}{c}\text { Simulation } \\
{[\mathrm{kWh}]}\end{array}$ & $\begin{array}{c}\text { Difference } \\
{[\%]}\end{array}$ \\
\hline 2009 & 20724 & 20810 & 0,41 \\
\hline 2010 & 20861 & 20888 & 0,13 \\
\hline 2011 & 22249 & 22016 & 1,05 \\
\hline 2012 & 22696 & 22892 & 0,86 \\
\hline 2013 & 19873 & 18975 & 4,52 \\
\hline 2014 & 19237 & 18680 & 2,90 \\
\hline 2015 & 20864 & 20399 & 2,23 \\
\hline 2016 & 20976 & 19781 & 5,70 \\
\hline 2017 & 20743 & 19636 & 5,34 \\
\hline 2018 & 20396 & 20903 & 2,43 \\
\hline Sum & 208619 & 204980 & 1,74 \\
\hline
\end{tabular}

To verify the accuracy and trueness of this comparision, respectively to avoid variations caused by changeable ambient conditions, the results were confronted to real meteo data. Fig. 10 shows average temperatures and it is evident that the variations in the Table IV correspond the real situation and can be classified as accurate.

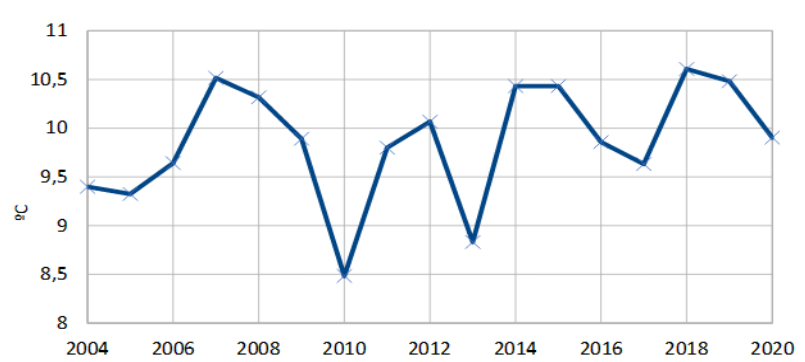

Fig. 10. Average temperatures (Pilsen, CR). 
Effect of the simulated method is evident in the Table V. Production and looses from the simulation is compared with nominal values typically used for predictions. These values are usually provided by the manufacturer.

Table V. - Difference between nominal values and simulation results

\begin{tabular}{|r|r|r|r|r|r|r|}
\hline & \multicolumn{3}{|c|}{ Nominal degradation (manufacturer) } & \multicolumn{3}{|c|}{ Simulation of degradation } \\
\hline & Looses PR (\%) & PR (\%) & E Grid (kWh/ yr ) & Looses PR (\%) & PR (\%) & E Grid $(\mathrm{kWh} / \mathrm{yr})$ \\
\hline 1 & 0 & 79,9 & 19900 & 0 & 79,9 & 19900 \\
\hline 2 & 2,8 & 77,1 & 19342,8 & 0,9 & 79 & 19720,9 \\
\hline 3 & 5,4 & 74,5 & 18825,4 & 1,8 & 78,1 & 19541,8 \\
\hline 4 & 7,8 & 72,1 & 18347,8 & 2,7 & 77,2 & 19362,7 \\
\hline 5 & 9,9 & 70 & 17929,9 & 3,6 & 76,3 & 19183,6 \\
\hline 6 & 11,8 & 68,1 & 17551,8 & 4,5 & 75,4 & 19004,5 \\
\hline 7 & 13,6 & 66,3 & 17193,6 & 5,4 & 74,5 & 18825,4 \\
\hline 8 & 15,1 & 64,8 & 16895,1 & 6,3 & 73,6 & 18646,3 \\
\hline 9 & 16,6 & 63,3 & 16596,6 & 7,2 & 72,7 & 18467,2 \\
\hline 10 & 17,9 & 62 & 16337,9 & 8,1 & 71,8 & 18288,1 \\
\hline 11 & 19,1 & 60,8 & 16099,1 & 9 & 70,9 & 18109 \\
\hline 12 & 20,1 & 59,8 & 15900,1 & 9,7 & 70,2 & 17969,7 \\
\hline 13 & 21,1 & 58,8 & 15701,1 & 10,4 & 69,5 & 17830,4 \\
\hline 14 & 22 & 57,9 & 15522 & 11,1 & 68,8 & 17691,1 \\
\hline 15 & 22,8 & 57,1 & 15362,8 & 11,8 & 68,1 & 17551,8 \\
\hline 16 & 23,5 & 56,4 & 15223,5 & 12,5 & 67,4 & 17412,5 \\
\hline 17 & 24,2 & 55,7 & 15084,2 & 13,2 & 66,7 & 17273,2 \\
\hline 18 & 24,8 & 55,1 & 14964,8 & 13,9 & 66 & 17133,9 \\
\hline 19 & 25,3 & 54,6 & 14865,3 & 14,6 & 65,3 & 16994,6 \\
\hline 20 & 25,8 & 54,1 & 14765,8 & 15,3 & 64,6 & 16855,3 \\
\hline
\end{tabular}

\section{Fault tree analysis}

FTA of a common PV power plant is built taking into account the data in Table 1, Table II and the correction curve. Basic chart of the tree is demonstrated on Fig. 11.

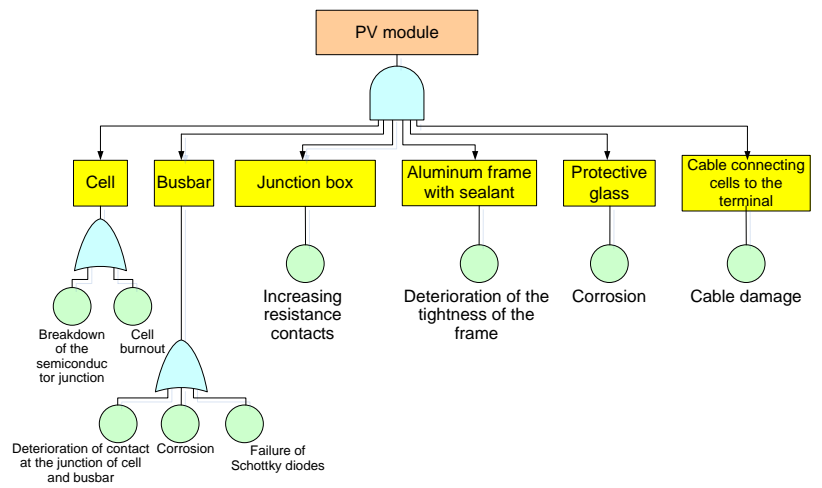

Fig. 11. FTA of PV power plant

To determine the real technical conditions and state of particular PV power plant, common diagnostic methods can be used [4].

That involves determining the technical condition of the PV module, electrical components and other parts. Detected features allow neuro-fuzzy modeling and expert evaluation in particular and to develop a neuro-fuzzy model of the residual life of the PV module. This model can be used to identify the PV module possible "emergency", "pre-emergency", "with minor deviations of parameters", "serviceable" statement and to predict future generation of the plant.

Firstly, we need to define residual resources coefficients for each diagnostic parameter for every PVM element. It is necessary to follow from known values of diagnostic parameters to the corresponding values of RRI for each diagnostic parameter. Therefore, RRI for each diagnostic parameter can be mathematically defined as follows (1) [9]:

$$
k_{i 1}=\left|\frac{x_{i 1, \text { lim }}-x_{i 1, \text { current }}}{x_{i 1, \text { lim }}-x_{i 1, \text { start }}}\right|
$$

where $x_{i 1 \text {,lim }}$ is limit value of the $\mathrm{i}$-th diagnostic parameter; $x_{i 1, \text { current }}$ is the value of the i-th diagnostic parameter at the time of detection; $x_{i 1, \text { start }}$ is the start value of the $i^{\text {th }}$ diagnostic parameter at the time of commissioning of new unit or after major repair.

If take into account, that the malfunction of each elements (noted in Table 1) results in a failure of the PV module (Fig. 11), then the total RRI PV modules is calculated using (2):

$$
k_{T R R}=\prod_{i=1}^{j} k_{i}^{p_{i}} .
$$

what is the total RRI of the PV module evaluated on the ith diagnostic parameter. Every controlled diagnostic parameter (temperature, insulation, resistance, current, etc.) affects the RRI of the PV module elements as evident in the equation (2). $k_{l}-k_{6}$ are RRI of every elements, that influence the total RRI of the PV module. $i$ is ith diagnostic parameter of elements of PV module, $j$ is the number of diagnostic parameters, and $p_{i}$ is the probability of deviations of the controlled parameter from the allowable limit value as shown in (3):

$$
p_{i}=\frac{y_{i}}{m},
$$

where $y_{i}$ is the number of deviations of the controlled parameter from the allowable boundary of normalized value of this parameter. These deviations are detected by controlling the $i^{\text {th }}$ diagnostic parameter from the total number of detected deviations of controlled parameters from the allowable boundary of normalized values, while $m$ is the total number of detected deviations of controlled diagnostic parameters allowable boundary of normalized values.

Expanding the expression (2), total PV module RRI becomes (4):

$$
k_{\text {tot.res }}=k_{1}^{p_{k 1}} \cdot k_{2}^{p_{k 2}} \cdot k_{3}^{p_{k 3}} \cdot k_{4}^{p_{k 4}} \cdot k_{5}^{p_{k 5}} \cdot k_{6}^{p_{k 6}}
$$

where $k_{1}, k_{2}, k_{3}, k_{4}, k_{5}, k_{6}$ are known at the time of calculation of the values of the RRI for the relevant diagnostic parameters, and $p_{k l}, p_{k 2}, p_{k 3}, p_{k 4}, p_{k 5}, p_{k 6}$ are the PV module node malfunction probabilities detected by measured of the diagnostic parameters taking into account total malfunction. These probabilities can be found in Table 1.

\section{Results and conclusion}

Fault tree analysis using neuro-fuzzy modeling can be used for fast or online detection of originating problem in its elementary stage. That can either prolong the lifecycle of affected components or decrease economical looses. 
Another serious effect can be found in better accuracy of power prediction and thus better prediction of conditions in the grid. This becomes more important because of more strict conditions defining proper operation of power sources including RES.

Key problem of this method is correct and accurate mathematic description of key components. This problem was for now solved only for monocrystalline Si panels as demonstrated in Table IV. The accuracy of this method is better than $2 \%$ in horizon of 10 years.

These results entitled further analysis. Remaining components should be described in similar way and entire system can be modelled with sufficient accuracy. Final model can be used for monitoring of commercial PV plants and for power generation prediction. This issue becomes more important in close future, when guaranteed power generation of particular RES will be required.

\section{References}

[1] IRENA, "Global Energy Transformation: A roadmap to 2050," International Renewable Energy Agency, Abu Dhabi 2018

[2] P. Moriarty and D. Honnery, "Global renewable energy resources and use in 2050," 2018, pp. 221-235.

[3] Installed capacity of the IPS of Ukraine values as of $02 / 2021$.

[4] O. Rubanenko and V. Yanovych, "Analysis of instability generation of Photovoltaic power station," in 2020 IEEE 7th International Conference on Energy Smart Systems, ESS 2020 - Proceedings, 2020, pp. 128-133

[5] https://www.energo.ua/en/assets/pysarivska_pv_plant_3_st age

[6] C. Cepisca and A. Florin, ANCUTA,F, CEPISCA,C Failure Analysis Capabilities for PV Systems. 2011.

[7] M. Belik, "Evaluation of long term degradation process of monocrystalline $\mathrm{Si}$ photovoltaic panels," Renewable Energy and Power Quality Journal, vol. 18, pp. 551-555, 06/01 2020

[8] Rubanenko O., Kazmiruk O., Bandura V., Matvichuk V., Determination of optimal transformation ratios of power system transformers in conditions of incomplete information regarding the values of diagnostic parameters. Eastern European Journal of Enterprise Technologies. 2017. № 4. Issue 3-88. P. 66-79 